University of Nebraska - Lincoln

DigitalCommons@University of Nebraska - Lincoln

Faculty Publications in Food Science and Technology

2011

\title{
IL-2 limits IL-12 enhanced lymphocyte proliferation during Leishmania amazonensis infection
}

Amanda E. Ramer-Tait

University of Nebraska-Lincoln, aramer-tait2@unl.edu

Christine A. Petersen

lowa State University

Douglas E. Jones

lowa State University, jonesdou@iastate.edu

Follow this and additional works at: https://digitalcommons.unl.edu/foodsciefacpub

Part of the Food Science Commons

Ramer-Tait, Amanda E.; Petersen, Christine A.; and Jones, Douglas E., "IL-2 limits IL-12 enhanced lymphocyte proliferation during Leishmania amazonensis infection" (2011). Faculty Publications in Food Science and Technology. 202.

https://digitalcommons.unl.edu/foodsciefacpub/202

This Article is brought to you for free and open access by the Food Science and Technology Department at DigitalCommons@University of Nebraska - Lincoln. It has been accepted for inclusion in Faculty Publications in Food Science and Technology by an authorized administrator of DigitalCommons@University of Nebraska Lincoln. 


\title{
Author Manuscript
}

Published in final edited form as:

Cell Immunol. 2011 ; 270(1): 32-39. doi:10.1016/j.cellimm.2011.03.016.

Copyright 2011 Elsevier. Used by permission.

\section{IL-2 limits IL-12 enhanced lymphocyte proliferation during Leishmania amazonensis infection}

\author{
Amanda E. Ramer-Tait ${ }^{a}{ }^{*}$, Christine A. Petersen ${ }^{\mathrm{a}}$, and Douglas E. Jones ${ }^{\mathrm{a}}$ \\ a Immunobiology Program and Department of Veterinary Pathology, College of Veterinary \\ Medicine, lowa State University, Ames, IA 50011-1250
}

\section{Abstract}

C3H mice infected with Leishmania amazonensis develop persistent, localized lesions with high parasite loads. During infection, memory/effector $\mathrm{CD} 44^{\mathrm{hi}} \mathrm{CD} 4{ }^{+} \mathrm{T}$ cells proliferate and produce IL-2, but do not polarize to a known effector phenotype. Previous studies have demonstrated IL-12 is insufficient to skew these antigen-responsive $\mathrm{T}$ cells to a functional Th1 response. To determine the mechanism of this IL-12 unresponsiveness, we used an in vitro assay of repeated antigen activation. Memory/effector $\mathrm{CD} 44^{\mathrm{hi}} \mathrm{CD} 4{ }^{+} \mathrm{T}$ cells did not increase proliferation in response to either IL-2 or IL-12, although these cytokines upregulated CD25 expression. Neutralization of IL-2 enhanced $\mathrm{CD}^{+}{ }^{+} \mathrm{T}$ cell proliferation in response to IL-12. This cross-regulation of IL-12 responsiveness by IL- 2 was confirmed in vivo by treatment with anti-IL- 2 antibodies and IL-12 during antigen challenge of previously infected mice. These results suggest that during chronic infection with L. amazonensis, IL-2 plays a dominant, immunosuppressive role independent of identifiable conventional $\mathrm{T}_{\text {reg }}$ cells.

\section{Keywords}

Leishmania; IL-2; IL-12; tolerance; T cell

\section{Introduction}

Infection of $\mathrm{C} 3 \mathrm{HeB} / \mathrm{FeJ}$ mice in the footpad with Leishmania amazonensis results in chronic lesions containing up to $10^{8}$ parasites. This chronic infection is accompanied by $\mathrm{CD} 4^{+} \mathrm{T}$ cell dysfunction with low to undetectable levels of the T cell effector cytokines IFN- $\gamma$ and IL-4 $[1 ; 2]$. Although $\mathrm{CD}^{+} \mathrm{T}$ regulatory $\left(\mathrm{T}_{\text {reg }}\right)$ cells, characterized by high surface expression of CD25 and intracellular expression of FoxP3, are often associated with chronic infections, Ji et al demonstrated that these cells played a limited role in driving chronic disease in $L$. amazonensis-infected mice [3]. The immune phenotype associated with L. amazonensis infection is in stark contrast to that observed when $\mathrm{C} 3 \mathrm{HeB} / \mathrm{FeJ}$ mice are infected with Leishmania major. L. major-infected mice heal via development of classic $\mathrm{CD} 4^{+} \mathrm{T}$ helper 1 (Th1) cell-mediated immunity through IL-12-dependent production of IFN- $\gamma$. However, treatment of $L$. amazonensis-infected mice with exogenous IL-12 fails to drive a successful

\footnotetext{
(C) 2011 Elsevier Inc. All rights reserved.

*Corresponding author. Mailing address: Department of Veterinary Microbiology and Preventive Medicine Room 1120, College of Veterinary Medicine, Iowa State University, Ames, IA 50011-1250. Phone: 515-294-0261. Fax: 515-294-8500. ramerae@ iastate.edu. Publisher's Disclaimer: This is a PDF file of an unedited manuscript that has been accepted for publication. As a service to our customers we are providing this early version of the manuscript. The manuscript will undergo copyediting, typesetting, and review of the resulting proof before it is published in its final citable form. Please note that during the production process errors may be discovered which could affect the content, and all legal disclaimers that apply to the journal pertain.
} 
immune response, and adoptive transfer of antigen-specific Th1 cells also fails to limit infection with $L$. amazonensis amastigotes [1;4].

The failure of exogenous IL-12 to promote resolution of this intracellular pathogen as well as the lack of any clear role for a $\mathrm{CD} 4^{+} \mathrm{T}_{\text {reg }}$ cell population in limiting immune effectiveness during this infectious disease indicates that unknown factors are restricting the development of an effective $\mathrm{CD} 4^{+} \mathrm{T}$ cell response. To that end, we sought to more closely examine the immune mechanisms responsible for the inability of IL-12 to promote an appropriate $\mathrm{CD}_{4}^{+}$Th1 response during L. amazonensis infection. We found that IL-12 did induce IFN- $\gamma$ production from memory/effector $\mathrm{CD} 44^{\text {hi }} \mathrm{CD} 4^{+} \mathrm{T}$ cells; however, that enhanced IFN- $\gamma$ production was limited in vitro and the response waned in vivo. In vitro experiments indicated that, in contrast to its well-described role as a proliferative cytokine, IL-2 was a potent immunoregulatory factor for $\mathrm{CD}^{+} \mathrm{T}$ cells derived from L. amazonensisinfected mice. Moreover, this regulation was mediated by limiting the proliferative response of $\mathrm{CD}^{+} \mathrm{T}$ cells to IL-12. Neutralization of IL-2 restored the IL-12 responsiveness of CD4 ${ }^{+}$ $\mathrm{T}$ cells in vivo during established infection. Together, these findings indicate that IL-2 plays a negative, immunoregulatory role during chronic $L$. amazonensis infection independent of classical $\mathrm{T}_{\text {reg }}$ cells. Our findings are consistent with recently described anti-proliferative functions for this cytokine during chronic antigen exposure $[5 ; 6]$.

\section{Materials and Methods}

\subsection{Parasites and antigens}

Culture of L. amazonensis (MHOM/BR/00/LTB0016) and L. major (MHOM/IL/80/Friedlin) and preparation of parasite antigens were performed as previously described [7].

\subsection{Mice}

Female $\mathrm{C} 3 \mathrm{HeB} / \mathrm{FeJ}$ mice (six to eight weeks of age) were either bred in-house or obtained from The Jackson Laboratory (Bar Harbor, ME) and maintained in a specific pathogen-free facility. Mice were injected with $5 \times 10^{6}$ stationary phase promastigotes in $50 \mu 1 \mathrm{PBS}$ in the left hind footpad. Between four and seven mice were used per group for each experiment and were sacrificed at four weeks post-infection. The IACUC at Iowa State University approved all protocols involving animals.

\subsection{In vivo IL-12 administration}

At the time of infection, a group of $L$. amazonensis-infected mice were also injected with 0.2 $\mu \mathrm{g}$ of IL-12 (Peprotech, Rocky Hill, NJ) as indicated. These mice received $0.2 \mu \mathrm{g}$ of IL-12 in $25 \mu \mathrm{l}$ of PBS intralesionally every other day for two weeks (a total of six injections) while control L. amazonensis-infected mice received PBS injections of $25 \mu \mathrm{l}$. Mice were sacrificed at either two or ten weeks post-infection as indicated in figure legends.

\section{4. $\mathrm{CD}^{+} \mathrm{T}$ cell purification}

$\mathrm{CD}^{+} \mathrm{T}$ cells were purified from lymph nodes via magnetic depletion (negative selection) using a biotin-conjugated antibody cocktail and anti-biotin MicroBeads (Miltenyi Biotec, Auburn, CA) according to the manufacturer's protocol. Cells were subjected to two passes through an AutoMACS cell sorter. The purity of the CD4 ${ }^{+} \mathrm{T}$ cells was routinely $90 \%$ or greater.

\subsection{Repeated antigen-activation assay}

This culture system was adapted from previously described protocols [8;9] as a method to provide purified $\mathrm{CD}^{+} \mathrm{T}$ cells with both a primary and secondary in vitro stimulation. All 
cultures were performed in duplicate or triplicate in 96-well U-bottom plates in a total volume of $200 \mu \mathrm{l}$ per well. One hundred thousand $\mathrm{CD}^{+} \mathrm{T}$ cells purified from the draining lymph node of either L. amazonensis- or L. major-infected mice were cultured with $2 \times 10^{5}$ mitomycin C-treated, carboxyfluorescein diacetate succinimidyl ester- (CFSE) labeled naïve splenocytes and $50 \mu \mathrm{g} / \mathrm{ml}$ freeze-thawed Leishmania promastigote $\mathrm{Ag}\left(\mathrm{CD} 4^{+} \mathrm{T}\right.$ cells isolated from $L$. major-infected mice were stimulated with $L$. major $\mathrm{Ag}$ and $\mathrm{CD} 4^{+} \mathrm{T}$ cells isolated from $L$. amazonensis-infected mice were stimulated with L. amazonensis $\mathrm{Ag}$ ) in complete tissue culture medium (CTCM; DMEM containing $4.5 \mathrm{mg}$ of glucose $/ \mathrm{ml}, 2 \mathrm{mM} \mathrm{L}$ glutamine, $100 \mathrm{U}$ penicillin, $100 \mu \mathrm{g}$ streptomycin/ml, $25 \mathrm{mM}$ HEPES, $0.05 \mu \mathrm{M} 2$ mercaptoethanol and $10 \%$ fetal bovine serum). Feeder splenocytes were prepared by incubating spleen cells from naïve female $\mathrm{C} 3 \mathrm{HeB} / \mathrm{FeJ}$ mice with a lysing buffer $(0.15 \mathrm{M}$ ammonium chloride, $10 \mathrm{mM}$ potassium bicarbonate and $0.1 \mathrm{mM}$ ethylenediaminetetra-acetic acid) to lyse red blood cells. After red blood cells lysis, splenocytes were labeled using CFSE (Molecular Probes, Eugene, OR) as previously described [1] and then treated with mitomycin C (Sigma, St. Louis, MO) at a final concentration of $50 \mu \mathrm{g} / \mathrm{ml}$ at $37^{\circ} \mathrm{C}$ for $20 \mathrm{~min}$ and washed five times with an excess of CTCM before co-culture with purified $\mathrm{CD} 4^{+} \mathrm{T}$ cells. Cultures were maintained in the presence of no exogenous cytokine (neutral conditions), $2 \mathrm{ng} / \mathrm{ml} \mathrm{IL-12} \mathrm{(Peprotech,} \mathrm{Rocky} \mathrm{Hill,} \mathrm{NJ),} 10 \mathrm{ng} / \mathrm{ml} \mathrm{IL-2} \mathrm{(Peprotech),} 10 \mu \mathrm{g} / \mathrm{ml}$ anti-IL-2 (S4B6, BD Biosciences, San Diego, CA), $10 \mu \mathrm{g} / \mathrm{ml}$ control antibody (R35-95, BD Biosciences) or in combinations as indicated. $\mathrm{CD}^{+} \mathrm{T}$ cells were rested for $48 \mathrm{hrs}$ on day three by removing $100 \mu \mathrm{l}$ of culture supernatant and replacing it with $100 \mu \mathrm{l}$ of medium containing $2 \times 10^{5}$ fresh feeder splenocytes without $\mathrm{Ag}$ and, depending on the culture conditions, cytokine or antibody at the final concentrations described above. $\mathrm{CD} 4^{+} \mathrm{T}$ cells were given a secondary restimulation on day five by removing $100 \mu \mathrm{l}$ of culture supernatant and replacing it with $100 \mu \mathrm{l}$ of medium containing $2 \times 10^{5}$ fresh feeder splenocytes with 20 $\mu \mathrm{g} / \mathrm{ml} \mathrm{Ag}$ and, depending on the culture conditions, cytokine or antibody at the final concentrations described above. Cultures were analyzed by flow cytometry or BrdU ELISA either $24 \mathrm{hrs}$ (primary stimulation) or three days after the secondary stimulation. Culture supernatants were removed for IFN- $\gamma$ ELISA on day three after the secondary stimulation. To determine the number of live $\mathrm{CD} 44^{\mathrm{hi}} \mathrm{CD} 4^{+} \mathrm{T}$ cells in culture as an assessment of cell accumulation, a known number of washed, surfactant-free white sulfate latex beads (Interfacial Dynamics Corporation, Portland, OR) were added to each well prior to harvest. Cells were stained and analyzed via flow cytometry. A bead ratio was generated by dividing the number of beads collected during FACS acquisition by the number of beads added to the well. The number of live $\mathrm{CD} 44^{\text {hi }} \mathrm{CD} 4^{+} \mathrm{T}$ cells collected was determined using a live lymphocyte gate and then divided by the bead ratio to calculate the number of live CD $44^{\text {hi }}$ $\mathrm{CD} 4^{+} \mathrm{T}$ cells present in each culture well.

\subsection{Flow cytometry}

To evaluate intracellular IFN- $\gamma 24-\mathrm{hr}$ after secondary stimulation, $\mathrm{T}$ cells were stimulated with PMA (50 ng/ml) and ionomycin $(50 \mathrm{ng} / \mathrm{ml})$ in the presence of brefeldin A $(10 \mu \mathrm{g} / \mathrm{ml})$ for six hrs prior to harvest. Cells were harvested, washed, stained with cychrome-labeled anti-CD44 (IM7, BD Biosciences) or the appropriate isotype controls and fixed. Intracellular IFN- $\gamma$ was assayed using PE-labeled anti-IFN- $\gamma$ (XMG1.2, BD Biosciences) as previously described (17). Cells were acquired on a FACScan flow cytometer (Becton Dickinson, San Jose, CA) and data were analyzed using Flowjo software (Tree Star, Ashland, OR). For all samples, the CFSE-labeled feeder layer was excluded from analysis of purified CD4 ${ }^{+} \mathrm{T}$ cells from infected mice. Surface staining for CD25 (PC61.5, eBioscience, San Diego, CA) was performed as previously described [1]. 


\subsection{ELISAs}

Supernatants were assayed via ELISA for IFN- $\gamma$. All IFN- $\gamma$ ELISA antibodies were purchased from Pharmingen and used according to manufacturer recommendations. Agpulsed mitomycin C-treated splenocytes alone were cultured under similar conditions as $\mathrm{CD}^{+} \mathrm{T}$ cells to determine baseline amount of cytokine production. BrdU ELISAs were conducted using the Cell Proliferation BrdU Colorimetric ELISA Kit (Roche Applied Science, Indianapolis, IN). Cultures were pulsed with $10 \mathrm{mM}$ BrdU for $12 \mathrm{hrs}$ and then transferred to flat-bottom 96-well plates before continuing with the manufacturer's protocol. Ag-pulsed mitomycin C-treated splenocytes alone were cultured under similar conditions as $\mathrm{CD}^{+} \mathrm{T}$ cells to determine baseline amount of BrdU incorporation.

\subsection{In vivo IL-2 inhibition}

For in vivo $\mathrm{Ag}$ challenge, L. amazonensis-infected mice four weeks post-infection were injected in the right hind (contralateral) footpad with $20 \mu \mathrm{g}$ of L. amazonensis $\mathrm{Ag}$ and/or 0.2 $\mu \mathrm{g}$ of IL-12 (Peprotech, Rocky Hill, NJ) and $30 \mu \mathrm{g}$ of either anti-mouse IL-2 (S4B6, BD Pharmingen) or Rat IgG2a, $\mathrm{K}$ isotype control (R35-95, Pharmingen) as indicated in a total volume of $50 \mu \mathrm{l}$ of PBS or with $50 \mu \mathrm{l}$ of PBS alone. Mice were sacrificed at 48 hours postAg challenge.

\subsection{Statistical Procedure}

Statistical analysis was performed using Statview (SAS, Cary, NC). For comparisons between two treatment groups, data were analyzed using an unpaired $t$ test. For comparisons of more than two treatment groups, data were analyzed with Scheffe's post-hoc test. When two treatments within a group were compared, data were analyzed using a paired t-test. Differences were considered significant when $\mathrm{p}<0.05$.

\section{Results}

\subsection{Exogeneous administration of IL-12 promotes a transient Th1 response in $L$. amazonensis-infected mice}

Previous work has shown that the administration of exogenous IL-12 at the time of $L$. amazonensis infection does not promote healing [1]. To assess the extent of T cell IL-12 responsiveness or lack thereof in vivo during $L$. amazonensis infection, mice were administered IL-12 at the time of infection and every other day for two weeks in the infected footpad. L. major-infected mice were used as a benchmark for a productive Th1 response. At two weeks post-infection, the draining lymph node (DLN) was removed and cells were stimulated with Ag. After 24 hours, the percentage of CD44hi CD4 ${ }^{+} \mathrm{IFN}-\gamma^{+} \mathrm{T}$ cells was significantly greater in IL-12-treated $L$. amazonensis-infected mice as compared to $L$. amazonensis-infected control mice (Figure 1A). Recall responses of DLN cells also showed a significant enhancement in IFN- $\gamma$ production from the $L$. amazonensis-infected mice treated with IL-12 compared to L. amazonensis-infected untreated mice (Figure 1B) or $L$. major-infect mice (data not shown). This increased amount of IFN- $\gamma$ production was similar to amounts produced by DLN cells from $L$. major-infected mice. This data indicates that exogenous IL-12 treatment at the time of $L$. amazonensis-infection is sufficient to promote a population of IFN- $\gamma$-producing cells. At ten weeks post-infection, however, the percent of $\mathrm{CD} 44^{\text {hi }} \mathrm{CD} 4^{+} \mathrm{T}$ cells producing IFN- $\gamma$ after a $24-\mathrm{hr}$ Ag stimulation was not significantly different between IL-12-treated and control L. amazonensis-infected mice at ten weeks PI (Figure 1C). Recall responses of DLN cells at ten weeks post-infection also showed no difference in IFN- $\gamma$ production between IL-12-treated and control L. amazonensis-infected mice (Figure 1D). The parasite burden in the infected footpad of IL-12-treated $L$. amazonensis-infected mice was also not significantly different from $L$. amazonensis-infected 
control mice (data not shown and as reported in [1]). Together, this data indicates that while L. amazonensis-infected mice do respond to exogenous IL-12 treatment by developing a Th1 response early after infection, that response is not maintained over time and the mice fail to heal their infection.

\section{2. $C D 44^{\mathrm{hi}} \mathrm{CD}^{+} \mathrm{T}$ cells from $L$. amazonensis-infected mice fail to accumulate in response to IL-12}

We wanted to evaluate this limited $\mathrm{CD}^{+} \mathrm{T}$ cell IL-12 responsiveness in a more controlled system to determine immunoregulatory mechanisms that may regulate Th1 cell development, function and persistence during L. amazonensis infection. $\mathrm{CD} 4^{+} \mathrm{T}$ cells were purified from DLN of mice at four weeks post-infection and co-cultured with Ag and mitomycin C-treated splenocytes from naïve mice (an APC feeder layer) as a primary stimulation. The cells were rested on day three of culture by adding fresh APC feeder cells without Ag. A secondary stimulation was provided on day five of culture using fresh Agpulsed APC feeder cells. CD4 ${ }^{+} \mathrm{T}$ cells isolated from $L$. major-infected mice were included as a positive control for a productive Th1 response. Each well contained the same number of memory/effector $\mathrm{CD} 44^{\mathrm{hi}} \mathrm{CD} 4^{+} \mathrm{T}$ cells at the beginning of the culture period [2]. After the second $\mathrm{Ag}$ restimulation under neutral conditions (no polarizing cytokines or antibodies), the percentage of $\mathrm{CD} 44^{\mathrm{hi}} \mathrm{CD} 4^{+} \mathrm{T}$ cells from $L$. amazonensis-infected mice that were positive for IFN- $\gamma$ was only $32 \%$ compared to those isolated from $L$. major-infected mice (Figure 2A). Likewise, the amount of IFN- $\gamma$ produced by T cells from L. amazonensisinfected mice, as determined by ELISA, was $29 \%$ of that produced by T cells from L. majorinfected mice (Figure 2B). Under Th1 polarizing conditions (IL-12), the percentage of IFN$\gamma$-positive CD44hi ${ }^{\mathrm{CD}} 4^{+} \mathrm{T}$ cells from $L$. amazonensis-infected animals increased and was equivalent to that of the same population isolated from L. major-infected animals (Figure 2C). Mean fluorescence intensities were also comparable between both cultures, indicating similar amounts of IFN- $\gamma$ produced per cell (data not shown). However, the amount of IFN- $\gamma$ detected via ELISA in culture supernatants of T cells from $L$. amazonensis-infected animals was only $60 \%$ of that produced by $\mathrm{T}$ cells from $L$. major-infected animals (Figure 2D).

Decreased total IFN- $\gamma$ produced by IL-12 stimulated T cells isolated from L. amazonensisinfected mice could be due to a reduced number of cells. In the presence of IL-12, the number of live CD44hi $\mathrm{CD}^{+} \mathrm{T}$ cells derived from the DLN of L. amazonensis-infected mice was $59 \%$ of those from L. major-infected mice (Figure 2E). This data suggests that the Th1 response elicited by IL-12 treatment of L. amazonensis infected animals may be limited, at least in part, by regulation of cell numbers. This decrease in cell number detected in vitro accounts for the lower amount of IFN- $\gamma$ detected in supernatants of Ag stimulated T cells from $L$. amazonensis-infected mice in response to IL-12.

\section{3. $\mathrm{CD}^{+} \mathrm{T}$ cells from $L$. amazonensis-infected mice have a partial response to IL-12 and IL-2}

Differences in the proliferative response between $\mathrm{CD} 4^{+} \mathrm{T}$ cells from $L$. amazonensis- and $L$. major-infected mice could be one factor leading to the disparity observed in live $\mathrm{CD}^{+} \mathrm{T}$ cell numbers after in vitro Ag stimulation in the presence of IL-12. Both IL-12 and IL-2 promote $\mathrm{CD}^{+} \mathrm{T}$ cell proliferation $[10 ; 11]$. ELISA analysis of BrdU incorporation at the end of the three-day primary stimulation demonstrated that there was no significant increase in BrdU incorporation when IL-12 was added to cultures of T cells from L. amazonensisinfected mice, whereas IL-12 significantly increased proliferation of T cells isolated from $L$. major-infected mice (Figure 3A). Flow cytometric analysis of BrdU incorporation confirmed that the differences existed almost exclusively in the $\mathrm{CD} 44^{\mathrm{hi}} \mathrm{CD} 4^{+} \mathrm{T}$ cell population (data not shown). 
IL-2 is an important T cell growth factor in vitro (reviewed in (32)). We assessed the effect of IL-2 on proliferation of T cells from L. amazonensis- and L. major-infected mice. T cells were stimulated with the appropriate Ag and IL-2 and BrdU incorporation was assessed via ELISA. There was no significant ( $\mathrm{p}=0.062)$ increase in BrdU incorporation observed in IL-2-treated T cells isolated from $L$. amazonensis-infected mice, whereas $\mathrm{CD} 4^{+} \mathrm{T}$ cells derived from L. major-infected mice had a significant increase in BrdU incorporation over cells stimulated in neutral conditions (Figure 3B). Neutralization of IL-2 in T cells isolated from $L$. amazonensis-infected mice had no effect on proliferation, whereas T cells from $L$. major-infected mice had significantly decreased BrdU incorporation (Figure 3C). Effector $\mathrm{CD}^{+} \mathrm{T}$ cells from $L$. amazonensis-infected mice are unresponsive to the proliferative effects of either IL-2 or IL-12 during primary Ag stimulation.

\section{4. $C D 44^{\text {hi }} C D 4^{+} T$ cells from $L$. amazonesis-infected animals become activated in vitro}

We measured expression of IL-2 receptor- $\alpha$ (CD25) on CD $44^{\text {hi }} \mathrm{CD} 4^{+} \mathrm{T}$ cells to closely follow the activation status of these cells during in vitro Ag stimulation. Immediately ex vivo, $20 \%$ of $\mathrm{CD}_{4} 4^{\text {hi }} \mathrm{CD}^{+} \mathrm{T}$ cells from $L$. amazonensis- and $L$. major-infected mice were $\mathrm{CD} 25^{+}$(Figure 4A). That percentage of $\mathrm{CD}^{2} 5^{+}$cells did not increase significantly after primary Ag stimulation in vitro. After a two-day rest however, the percentage of CD44 ${ }^{\text {hi }}$ $\mathrm{CD} 4^{+} \mathrm{T}$ cells that were $\mathrm{CD} 25^{+}$more than doubled for both cultures and continued to increase similarly during secondary restimulation. Three days after the secondary restimulation, over $80 \%$ of the $\mathrm{CD} 44^{\mathrm{hi}} \mathrm{CD} 4^{+} \mathrm{T}$ cells were $\mathrm{CD} 25^{+}$in both cultures, demonstrating similar activation kinetics of both $\mathrm{CD}^{+} \mathrm{T}$ cell populations (data not shown). However, the mean fluorescence intensity (MFI) of CD25 expression on CD $44^{\text {hi }} \mathrm{CD} 4^{+} \mathrm{T}$ cells from $L$. amazonensis-infected mice at the end of culture was $237 \pm 8.2$, which was significantly brighter than cells from L. major cultures with a MFI of $100 \pm 5.7$ (Figure 4B). Neutralizing IL-2 in vitro significantly reduced CD25 expression on CD44 ${ }^{\text {hi }} \mathrm{CD} 4{ }^{+} \mathrm{T}$ cells from $L$. amazonensis-infected mice (Figure $4 C$ ) while the addition of exogenous IL-2 to the cultures significantly increased CD25 expression on cells from $L$. major-infected mice (Figures $4 \mathrm{D}$ ). There is a population of resting effector CD $44^{\mathrm{hi}} \mathrm{CD} 4^{+} \mathrm{T}$ cells from $L$. amazonensis-infected mice that become activated and maintain IL-2-dependent, high expression of CD25.

\subsection{IL-2 limits $C D 4^{+} T$ cell proliferation in response to IL-12 in vitro}

Synergy between IL-2 and IL-12 to promote $\mathrm{CD} 4^{+} \mathrm{T}$ cell proliferation has been described previously $[10 ; 11]$. We wanted to determine if any aspects of this synergy occur within the $\mathrm{T}$ cell population during L. amazonensis infection. During secondary restimulation, these $\mathrm{T}$ cells failed to enhance proliferation in the presence of IL-2 and/or IL-12 (Figure 5A, line graph). In fact, BrdU incorporation was significantly decreased in the presence of combined IL-2 and IL-12. As we already demonstrated that CD $44^{\text {hi }} \mathrm{CD} 4^{+} \mathrm{T}$ cells from $L$. amazonensis-infected mice are responsive to IL-2, as shown by regulation of CD25 expression (Figure 4A), we wanted to determine if IL-2 was involved in regulating the proliferation rate of this $\mathrm{CD}^{+} \mathrm{T}$ cell population in response to IL-12. Neutralizing IL-2 significantly increased cell proliferation (Figure 5B, line graph). Furthermore, $\mathrm{CD} 4^{+} \mathrm{T}$ cells from $L$. amazonensis-infected mice maintained in the presence of IL-2 and/or IL-12 had a small but significant increase in cell numbers, while neutralization of IL-2 throughout the entire culture period resulted in a small but significant decrease in cell numbers (Figure 5 black bars), indicating that IL-2 and IL-12 promote cell survival independent of their role in proliferation. Taken together, these results indicate that IL-2 suppresses IL-12 mediated proliferation of $\mathrm{CD}^{+} \mathrm{T}$ cells derived from L. amazonensis-infected animals. 


\subsection{IL-2 limits lymphocyte proliferation in response to IL-12 in vivo}

To determine if IL-2 may limit IL-12 immune cell responsiveness in vivo, mice infected with $L$. amazonensis for four weeks were challenged in the contralateral footpad with antigen in addition to either anti-IL-2 or an isotype control antibody \pm IL-12. After 48 hours, the lymph node cells draining the site of Ag challenge were harvested, stimulated in vitro with $\mathrm{Ag}$ and assessed for BrdU incorporation as described in materials and methods. BrdU incorporation was significantly enhanced in the lymph node cells from animals treated with IL-12 and anti-IL-2 antibody as compared to mice treated with PBS, IL-12 alone or antiIL-2 alone (Figure 6).

\section{Discussion}

IL-2 may be a significant factor in limiting the immune response during $L$. amazonensis infection as it limits $\mathrm{CD}^{+} \mathrm{T}$ cell responsiveness to IL-12. Our data show that neither IL-2 nor IL-12 enhanced $\mathrm{CD} 4^{+} \mathrm{T}$ cell proliferation after L. amazonensis infection (Figures 3 and 5). Instead, IL-2 played a negative role by limiting the ability of IL- 12 to promote $\mathrm{CD} 4^{+} \mathrm{T}$ cell proliferation in vitro (Figure 5). Consistent with these in vitro results, neutralization of IL-2 during chronic $L$. amazonensis infection in vivo promoted enhanced lymphocyte proliferation in response to antigen challenge and IL-12 (Figure 6). Together, these results indicate that IL-2 suppresses enhanced cellular proliferation in response to IL-12 during the immune response to L. amazonensis, and IL-2 may play a significant role in limiting the establishment of a Th1 response.

Both IL-2 and IL-12 can promote proliferation through the phosphatidylinositol 3-kinase (PI3-K) pathway [12; 13; 14]. It is tempting to speculate that regulation of this pathway after L. amazonensis infection could account for antigen-responsive $\mathrm{CD}^{+} \mathrm{T}$ cell refractoriness to both of these cytokines. Recent evidence indicates that PI3-K signaling and its regulation by Phosphatase and Tensin homologue (PTEN) serves a critical role in the regulation and maintenance of conventional CD4 ${ }^{+} \mathrm{CD} 25^{+} \mathrm{T}_{\text {reg }}$ cells in response to IL-2 [15]. Perhaps the development of an antigen responsive $\mathrm{CD} 25$ bright $\mathrm{CD} 4^{+} \mathrm{T}$ cell population (Figure 4) reflects a regulatory mechanism related to the development of $\mathrm{T}_{\text {reg }}$ cells [16]. However, it is unlikely that conventional $\mathrm{T}_{\text {reg }}$ cells are responsible for the ex vivo immunoregulation described (Figure 1A) because we only find a deficiency in $\mathrm{T}$ cell proliferation in response to IL-2 and IL-12 (and not antigen alone) and we do not detect increased percentages of $\mathrm{CD} 25^{+} \mathrm{CD} 4^{+} \mathrm{T}$ cells. Furthermore, previous studies have indicated that IL-12 responsiveness of Th1 cells is not influenced by conventional Treg function [17].

IL-2 has two opposing functions in T cell biology: potentiating $\mathrm{T}$ cell proliferation and terminating T cell responses $[18 ; 19 ; 20]$. IL-2 has been described as a potent stimulator of naïve $\mathrm{T}$ cell growth and proliferation in vitro [20]. More recently, however, its primary role in vivo has been described as one for maintaining tolerance instead of amplifying $\mathrm{T}$ cell responses [21]. The most well-characterized mechanism by which IL-2 elicits its tolerogenic influence in vivo is via $T_{\text {reg }}$ cells, most of which constitutively express the high affinity IL-2 receptor- $\alpha$, CD25 $[18 ; 19]$. There are indications that the role of IL-2-mediated negative immunoregulation may be more diverse than just maintaining $\mathrm{T}_{\text {reg }}$ cells [6]. For example, IL-2 has also been shown to promote stimulation refractoriness in activated $\mathrm{CD} 4^{+} \mathrm{T}$ cells cultured in the presence of IL-2 [22; 23; 24]. Our data suggest that Ag responsive CD4 ${ }^{+} \mathrm{T}$ cells from L. amazonensis-infected mice may experience a form of IL-2-mediated refractoriness.

The tunable activation threshold (TAT) model proposed by Grossman and Paul states that $\mathrm{T}$ cell activation is a threshold phenomenon, that the threshold is tuned by the stimulatory experience of the cell, and that the strength and quality of antigenic stimulation, as well as 
the amount of antigen present during stimulation, all influence the $\mathrm{T}$ cell response [25;26]. In this model, under conditions of recurrent or continual antigen stimulation, changes in the balance between self-renewal and differentiation could lead to several different effector cell responses, including cell death or proliferation with or without effector function $[26 ; 27 ; 28]$. Recent studies in mice chronically infected with Schistosoma demonstrated a loss of CD4 ${ }^{+} \mathrm{T}$ cell effector function over time that was related to chronic antigen exposure and may reflect a tuning process for antigen specific cells [29]. We would suggest that, under conditions of local chronic infections with high parasite loads, persistent levels of IL-2 produced by chronically restimulated antigen-specific $\mathrm{CD} 4^{+} \mathrm{T}$ cells may promote the survival of an unpolarized $\mathrm{T}$ cell population and limit the expansion of $\mathrm{Th} 1 \mathrm{CD}^{+} \mathrm{T}$ cells even in the presence of IL-12 [5; 30].

Experimental L. amazonensis infection in the mouse is a localized infection characterized by the absence of a robust inflammatory response, as evidenced by decreased IL-12 production and decreased mRNA expression of multiple inflammatory mediators $[1 ; 31 ; 32]$, as well as by a high parasite load due to enhanced resistance of the parasite to macrophage-mediated killing $[33 ; 34 ; 35 ; 36]$. We propose that the $\mathrm{CD} 44^{\mathrm{hi}} \mathrm{CD} 4^{+} \mathrm{T}$ cells present in vivo during $L$. amazonensis infection have adapted to the continual high local parasite load by becoming functionally tolerant. Our data suggests that IL-2 plays an important role in the establishment of this tolerance independent of conventional $\mathrm{T}_{\text {reg }}$ cells.

\section{Acknowledgments}

This work was supported by NIH grant AI48357 to DEJ and the Biotechnology Council and College of Veterinary Medicine at Iowa State University to CAP and DEJ. We would like to thank Dennis Byrne for his technical assistance.

\section{References}

1. Jones DE, Buxbaum LU, Scott P. IL-4-independent inhibition of IL-12 responsiveness during Leishmania amazonensis infection. J Immunol. 2000; 165:364-72. [PubMed: 10861073]

2. Ramer AE, Vanloubbeeck YF, Jones DE. Antigen-responsive $\mathrm{CD}^{+}{ }^{+} \mathrm{T}$ cells from $\mathrm{C} 3 \mathrm{H}$ mice chronically infected with Leishmania amazonensis are impaired in the transition to an effector phenotype. Infect Immun. 2006; 74:1547-54. [PubMed: 16495525]

3. Ji J, Masterson J, Sun J, Soong L. CD $4^{+} \mathrm{CD} 25^{+}$regulatory T cells restrain pathogenic responses during Leishmania amazonensis infection. J Immunol. 2005; 174:7147-53. [PubMed: 15905558]

4. Qi H, Ji J, Wanasen N, Soong L. Enhanced replication of Leishmania amazonensis amastigotes in gamma interferon-stimulated murine macrophages: implications for the pathogenesis of cutaneous leishmaniasis. Infect Immun. 2004; 72:988-95. [PubMed: 14742545]

5. Knoechel B, Lohr J, Kahn E, Bluestone JA, Abbas AK. Sequential development of interleukin 2dependent effector and regulatory $\mathrm{T}$ cells in response to endogenous systemic antigen. J Exp Med. 2005; 202:1375-86. [PubMed: 16287710]

6. Rakoff-Nahoum S, Hao L, Medzhitov R. Role of toll-like receptors in spontaneous commensaldependent colitis. Immunity. 2006; 25:319-29. [PubMed: 16879997]

7. Jones DE, Ackermann MR, Wille U, Hunter CA, Scott P. Early enhanced Th1 response after Leishmania amazonensis infection of C57BL/6 interleukin-10-deficient mice does not lead to resolution of infection. Infect Immun. 2002; 70:2151-8. [PubMed: 11895981]

8. Blander JM, Sant'Angelo DB, Metz D, Kim SW, Flavell RA, Bottomly K, Janeway CA Jr. A pool of central memory-like CD4 T cells contains effector memory precursors. J Immunol. 2003; 170:2940-8. [PubMed: 12626545]

9. Pfeiffer C, Murray J, Madri J, Bottomly K. Selective activation of Th1- and Th2-like cells in vivo-response to human collagen IV. Immunol Rev. 1991; 123:65-84. [PubMed: 1684784]

10. Chan SH, Perussia B, Gupta JW, Kobayashi M, Pospisil M, Young HA, Wolf SF, Young D, Clark $\mathrm{SC}$, Trinchieri G. Induction of interferon gamma production by natural killer cell stimulatory 
factor: characterization of the responder cells and synergy with other inducers. J Exp Med. 1991; 173:869-79. [PubMed: 1672545]

11. Kobayashi M, Fitz L, Ryan M, Hewick RM, Clark SC, Chan S, Loudon R, Sherman F, Perussia B, Trinchieri G. Identification and purification of natural killer cell stimulatory factor (NKSF), a cytokine with multiple biologic effects on human lymphocytes. J Exp Med. 1989; 170:827-45. [PubMed: 2504877]

12. Ahmed NN, Grimes HL, Bellacosa A, Chan TO, Tsichlis PN. Transduction of interleukin-2 antiapoptotic and proliferative signals via Akt protein kinase. Proc Natl Acad Sci U S A. 1997; 94:3627-32. [PubMed: 9108028]

13. Brennan P, Babbage JW, Burgering BM, Groner B, Reif K, Cantrell DA. Phosphatidylinositol 3kinase couples the interleukin-2 receptor to the cell cycle regulator E2F. Immunity. 1997; 7:67989. [PubMed: 9390691]

14. Yoo JK, Cho JH, Lee SW, Sung YC. IL-12 provides proliferation and survival signals to murine $\mathrm{CD}^{+}{ }^{+} \mathrm{T}$ cells through phosphatidylinositol 3-kinase/Akt signaling pathway. J Immunol. 2002; 169:3637-43. [PubMed: 12244155]

15. Buckler JL, Liu X, Turka LA. Regulation of T-cell responses by PTEN. Immunol Rev. 2008; 224:239-48. [PubMed: 18759931]

16. Bensinger SJ, Walsh PT, Zhang J, Carroll M, Parsons R, Rathmell JC, Thompson CB, Burchill MA, Farrar MA, Turka LA. Distinct IL-2 receptor signaling pattern in $\mathrm{CD} 4{ }^{+} \mathrm{CD} 25^{+}$regulatory $\mathrm{T}$ cells. J Immunol. 2004; 172:5287-96. [PubMed: 15100267]

17. King IL, Segal BM. Cutting edge: IL-12 induces $\mathrm{CD} 4{ }^{+} \mathrm{CD} 25^{-} \mathrm{T}$ cell activation in the presence of T regulatory cells. J Immunol. 2005; 175:641-5. [PubMed: 16002658]

18. Malek TR, Bayer AL. Tolerance, not immunity, crucially depends on IL-2. Nat Rev Immunol. 2004; 4:665-74. [PubMed: 15343366]

19. Nelson BH. IL-2, regulatory T cells, and tolerance. J Immunol. 2004; 172:3983-8. [PubMed: 15034008]

20. Smith KA. Interleukin-2: inception, impact, and implications. Science. 1988; 240:1169-76. [PubMed: 3131876]

21. Malek TR. The biology of interleukin-2. Annu Rev Immunol. 2008; 26:453-79. [PubMed: 18062768]

22. Duthoit CT, Nguyen P, Geiger TL. Antigen nonspecific suppression of T cell responses by activated stimulation-refractory $\mathrm{CD}^{+}{ }^{+} \mathrm{T}$ cells. J Immunol. 2004; 172:2238-46. [PubMed: 14764692]

23. Norris MS, McConnell TJ, Mannie MD. Interleukin-2 promotes antigenic reactivity of rested T cells but prolongs the postactivational refractory phase of activated T cells. Cell Immunol. 2001; 211:51-60. [PubMed: 11585388]

24. Wilde DB, Prystowsky MB, Ely JM, Vogel SN, Dialynas DP, Fitch FW. Antigen-reactive cloned helper T cells. II. Exposure of murine cloned helper T cells to IL 2-containing supernatant induces unresponsiveness to antigenic restimulation and inhibits lymphokine production after antigenic stimulation. J Immunol. 1984; 133:636-41. [PubMed: 6234354]

25. Grossman Z, Paul WE. Adaptive cellular interactions in the immune system: the tunable activation threshold and the significance of subthreshold responses. Proc Natl Acad Sci U S A. 1992; 89:10365-9. [PubMed: 1438221]

26. Grossman Z, Paul WE. Self-tolerance: context dependent tuning of T cell antigen recognition. Semin Immunol. 2000; 12:197-203. discussion 257-344. [PubMed: 10910740]

27. Grossman Z. Recognition of self, balance of growth and competition: horizontal networks regulate immune responsiveness. Eur J Immunol. 1982; 12:747-56. [PubMed: 6982821]

28. Grossman Z, Min B, Meier-Schellersheim M, Paul WE. Concomitant regulation of T-cell activation and homeostasis. Nat Rev Immunol. 2004; 4:387-95. [PubMed: 15122204]

29. Taylor JJ, Krawczyk CM, Mohrs M, Pearce EJ. Th2 cell hyporesponsiveness during chronic murine schistosomiasis is cell intrinsic and linked to GRAIL expression. J Clin Invest. 2009; 119:1019-28. [PubMed: 19258704]

30. Singh NJ, Schwartz RH. The strength of persistent antigenic stimulation modulates adaptive tolerance in peripheral CD4 ${ }^{+}$T cells. J Exp Med. 2003; 198:1107-17. [PubMed: 14530379] 
31. Ji J, Sun J, Soong L. Impaired expression of inflammatory cytokines and chemokines at early stages of infection with Leishmania amazonensis. Infect Immun. 2003; 71:4278-88. [PubMed: 12874303]

32. Vanloubbeeck YF, Ramer AE, Jie F, Jones DE. CD4 ${ }^{+}$Th1 cells induced by dendritic cell-based immunotherapy in mice chronically infected with Leishmania amazonensis do not promote healing. Infect Immun. 2004; 72:4455-63. [PubMed: 15271903]

33. Gomes IN, Calabrich AF, Tavares Rda S, Wietzerbin J, de Freitas LA, Veras PS. Differential properties of $\mathrm{CBA} / \mathrm{J}$ mononuclear phagocytes recovered from an inflammatory site and probed with two different species of Leishmania. Microbes Infect. 2003; 5:251-60. [PubMed: 12706438]

34. Mukbel R, Petersen CA, Jones DE. Soluble factors from Leishmania major-specific CD4 ${ }^{+} \mathrm{T}$ cells and B cells limit L. amazonensis amastigote survival within infected macrophages. Microbes Infect. 2006; 8:2547-55. [PubMed: 16934514]

35. Mukbel RM, Patten C Jr, Gibson K, Ghosh M, Petersen C, Jones DE. Macrophage killing of Leishmania amazonensis amastigotes requires both nitric oxide and superoxide. Am J Trop Med Hyg. 2007; 76:669-75. [PubMed: 17426168]

36. Scott $P$, Sher A. A spectrum in the susceptibility of leishmanial strains to intracellular killing by murine macrophages. J Immunol. 1986; 136:1461-6. [PubMed: 3511147] 
A

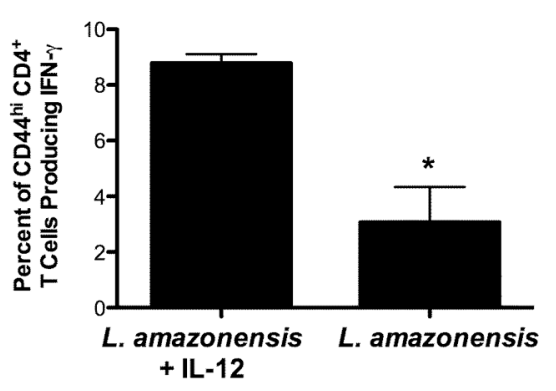

C

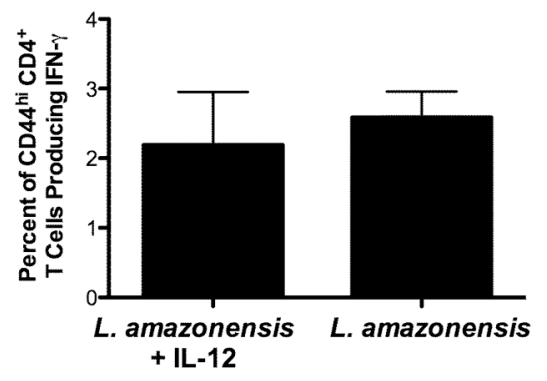

B

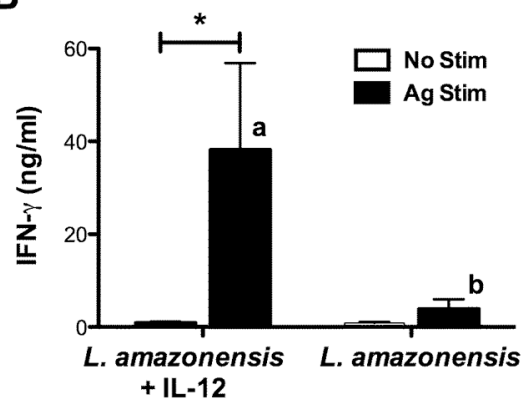

D

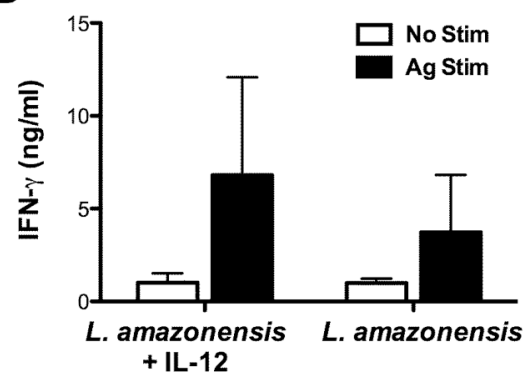

2 wks pi

10 wks pi

Figure 1.

Exogeneous administration of IL-12 promotes a transient Th1 response in L. amazonensisinfected mice. DLN cells were harvested at either (A) two weeks post-infection (p.i.) or (C) ten weeks p.i., stimulated for $24 \mathrm{~h}$ with $50 \mu \mathrm{g} / \mathrm{ml}$ of L. amazonensis $\mathrm{Ag}$, stained with fluorescent antibodies against CD4, CD44 and IFN- $\gamma$ and then analyzed by flow cytometry as described in materials and methods. Data are represented as the mean \pm the SEM of three separate experiments. * represents a statistically significant difference from all other groups at $p<0.05$ as determined by unpaired $t$ test. DLN cells harvested at either (B) two weeks p.i. or (D) ten weeks p.i. were stimulated for three days in the presence (Ag Stim) or absence (No Stim) of $50 \mu \mathrm{g} / \mathrm{ml}$ of Ag; supernatants were assayed for IFN- $\gamma$ via ELISA. Data are represented as the mean \pm the SEM of five separate experiments. * represents a statistically significant difference between No Stim and Ag Stim within a group at $\mathrm{p}<0.05$ as determined by paired $t$ test. Ag stim groups with different superscripts are significantly different from one another at $\mathrm{p}<0.05$ as determined by unpaired $t$ test. 
A

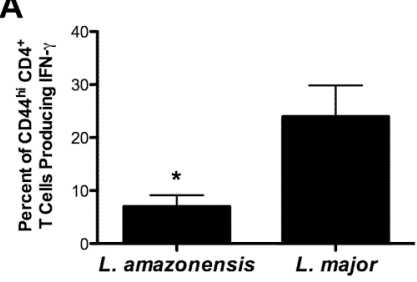

C

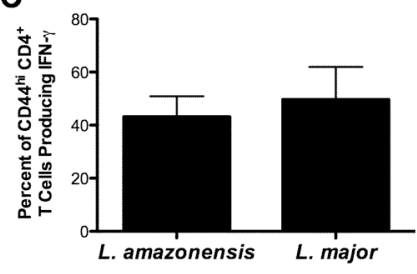

B

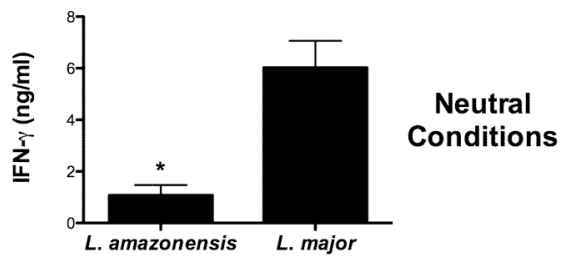

D

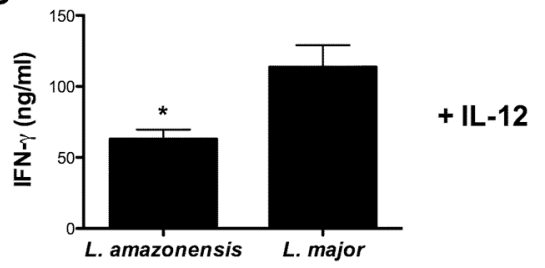

E

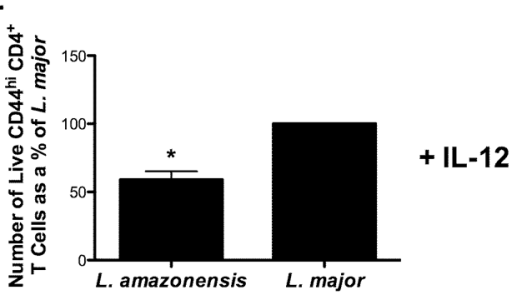

Figure 2.

CD $44^{\text {hi }} \mathrm{CD}^{+} \mathrm{T}$ cells from $L$. amazonensis-infected mice fail to accumulate in response to IL-12. CD4 ${ }^{+} \mathrm{T}$ cells from the DLN of L. amazonensis- and L. major-infected C3H mice were cultured as described in materials and methods either in the absence (A \& B) or presence (C, D \& E) of IL-12. (A) T cells cultured under neutral conditions were harvested 24 hours post-secondary Ag restimulation and assayed via flow cytometry for CD44 and IFN- $\gamma$ expression. (B) Supernatants from T cells cultured under neutral conditions were harvested three days post-secondary Ag restimulation and assayed via ELISA. (C) T cells cultured in the presence of IL-12 were harvested 24 hours post-secondary Ag restimulation and assayed via flow cytometry for CD44 and IFN- $\gamma$ expression. (D) Supernatants from T cells cultured in the presence of IL-12 were harvested three days post-secondary Ag restimulation and assayed via ELISA. (E) T cells were cultured and harvested as in $\mathrm{C}$ and assayed via flow cytometry for CD44 expression. The number of CD44 ${ }^{\text {hi }} \mathrm{CD} 4{ }^{+} \mathrm{T}$ cells was determined as in materials and methods; number of CD44 ${ }^{\text {hi }} \mathrm{CD} 4^{+} \mathrm{T}$ cells present in cultures of $\mathrm{T}$ cells from $L$. amazonensis-infected mice is expressed as a percentage of the number of $\mathrm{CD} 44^{\text {hi }} \mathrm{CD}^{+}{ }^{+} \mathrm{T}$ cells present in cultures of $\mathrm{T}$ cells from $L$. major-infected mice. For all panels, data are represented as the mean \pm the SEM of nine (A, B \& D) or six (C \& E) separate experiments. * represents a statistically significant difference from $L$. major at $\mathrm{p}<$ 0.05 as determined by unpaired t test. 
A

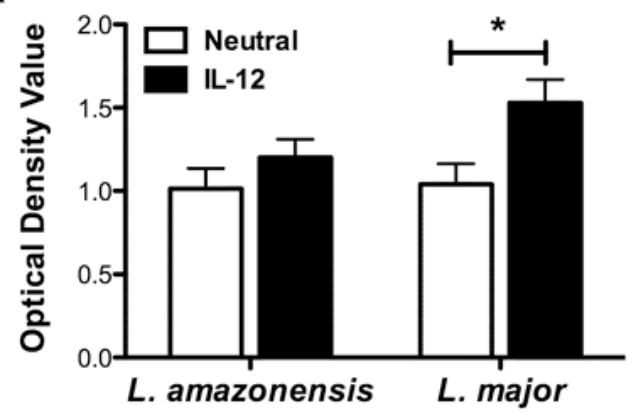

B

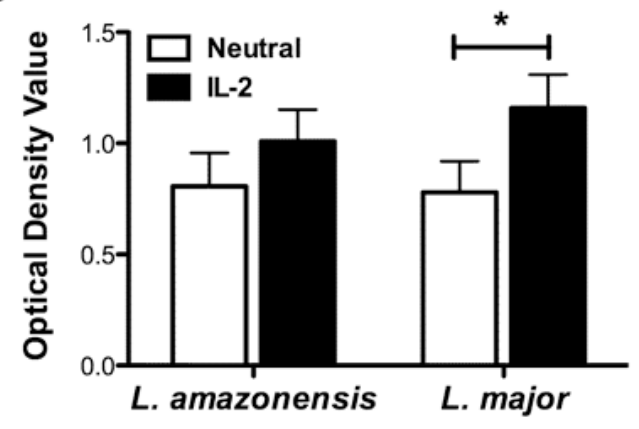

C

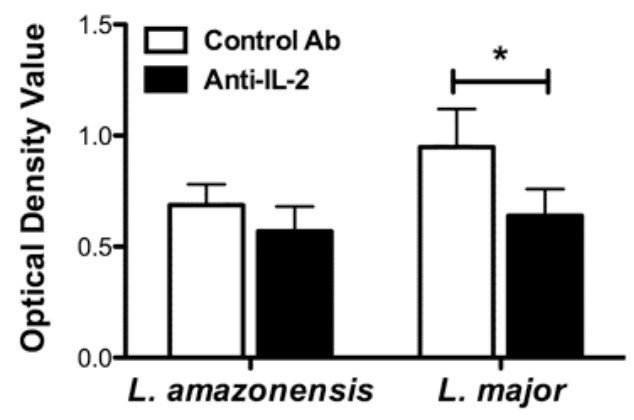

Figure 3.

$\mathrm{CD}^{+} \mathrm{T}$ cells from $L$. amazonensis-infected mice have an incomplete proliferative response to IL-12 and IL-2. (A) Cells were cultured in the presence or absence of IL-12 for three days post-primary Ag stimulation and pulsed with BrdU during the final 12 hours of culture. BrdU incorporation was assessed via ELISA. (B) Cells were cultured in the presence or absence of IL-2 or (C) with either a neutralizing antibody against IL-2 or a control antibody for three days post-primary Ag stimulation and pulsed with BrdU during the final 12 hours of culture. BrdU incorporation was assessed via ELISA. For all panels, data are represented as the mean \pm the SEM of four separate experiments. * represents a statistically significant difference between treatments within a group at $p<0.05$ as determined by paired $t$ test. 
A

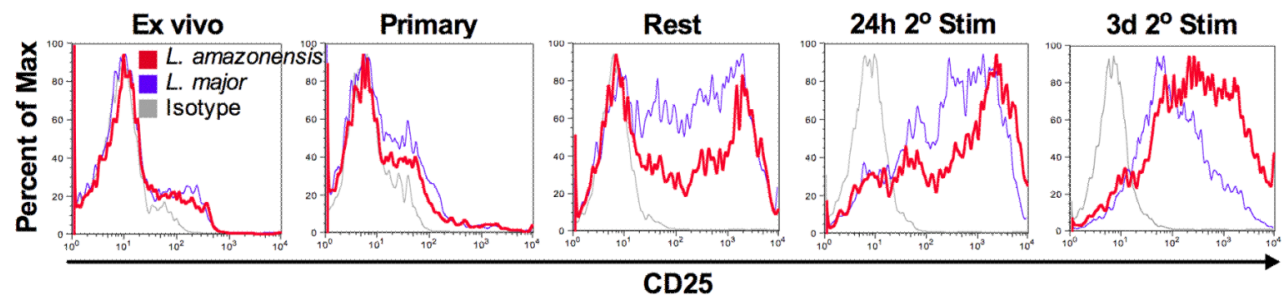

B

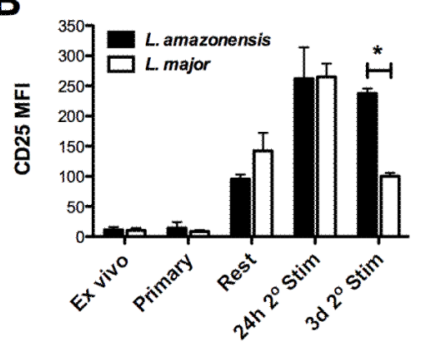

C

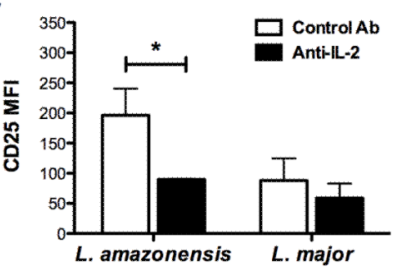

D

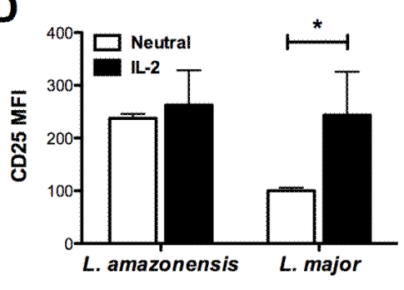

Figure 4.

CD $44^{\text {hi }} \mathrm{CD}^{+} \mathrm{T}$ cells from L. amazonesis-infected animals become activated in vitro. (A) CD25 expression at various timepoints; histograms are based on live, CD $44^{\text {hi }} \mathrm{CD} 4^{+} \mathrm{T}$ cell gates and are representative of two to four experiments (gray line, isotype control; blue line, L. major; red line, L. amazonensis). (B) The mean fluorescence intensity (MFI) of CD25 surface expression on CD $44^{\text {hi }} \mathrm{CD} 4{ }^{+} \mathrm{T}$ cells was determined via flow cytometry at various timepoints. Data are represented as the mean \pm the SEM of three to four separate experiments. * represents a statistically significant difference at $\mathrm{p}<0.05$ as determined by unpaired t test between L. amazonensis and L. major within a timepoint. (C) The mean fluorescence intensity of CD25 expression on CD44 ${ }^{\text {hi }} \mathrm{CD} 4^{+} \mathrm{T}$ cells after culture with a neutralizing antibody to IL-2 (black bar) or a control antibody (white bar) was determined via flow cytometry at three days post-secondary Ag restimulation. Data are represented as the mean \pm the SEM of three separate experiments. * represents a statistically significant difference between treatments within a group at $\mathrm{p}<0.05$ as determined by paired test. (D) $\mathrm{CD}^{+} \mathrm{T}$ cells were cultured in the presence (black bar) or absence (white bar) of exogenous IL-2 as described in materials and methods and analyzed as described in (C). 
A

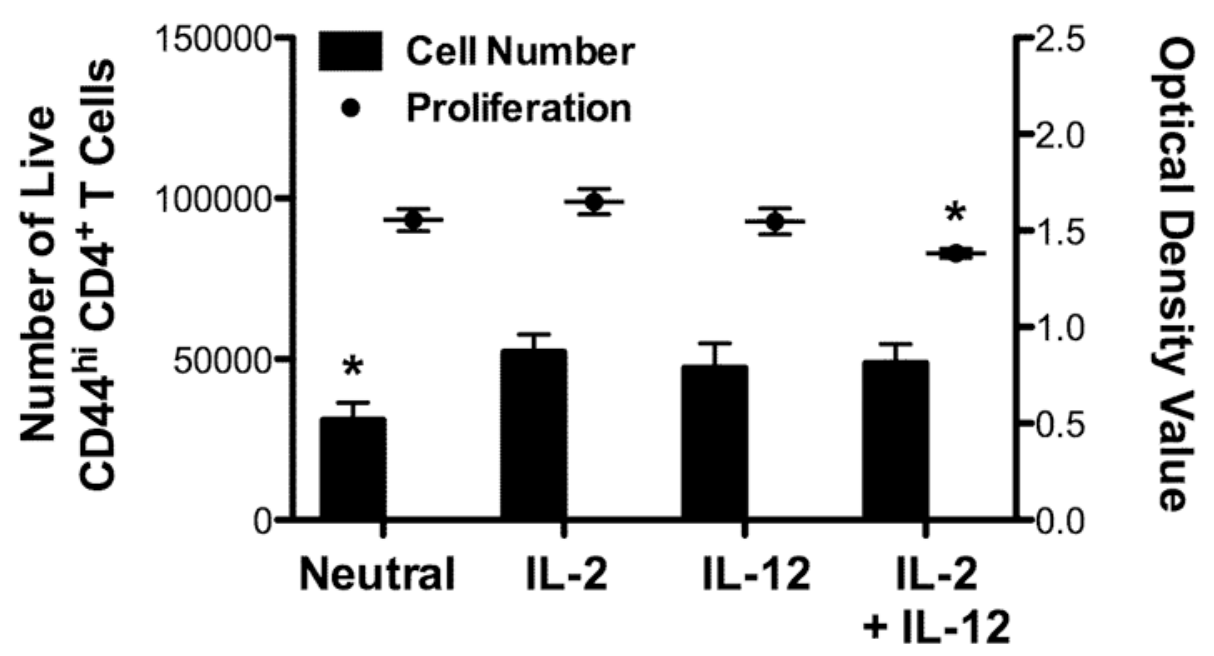

B

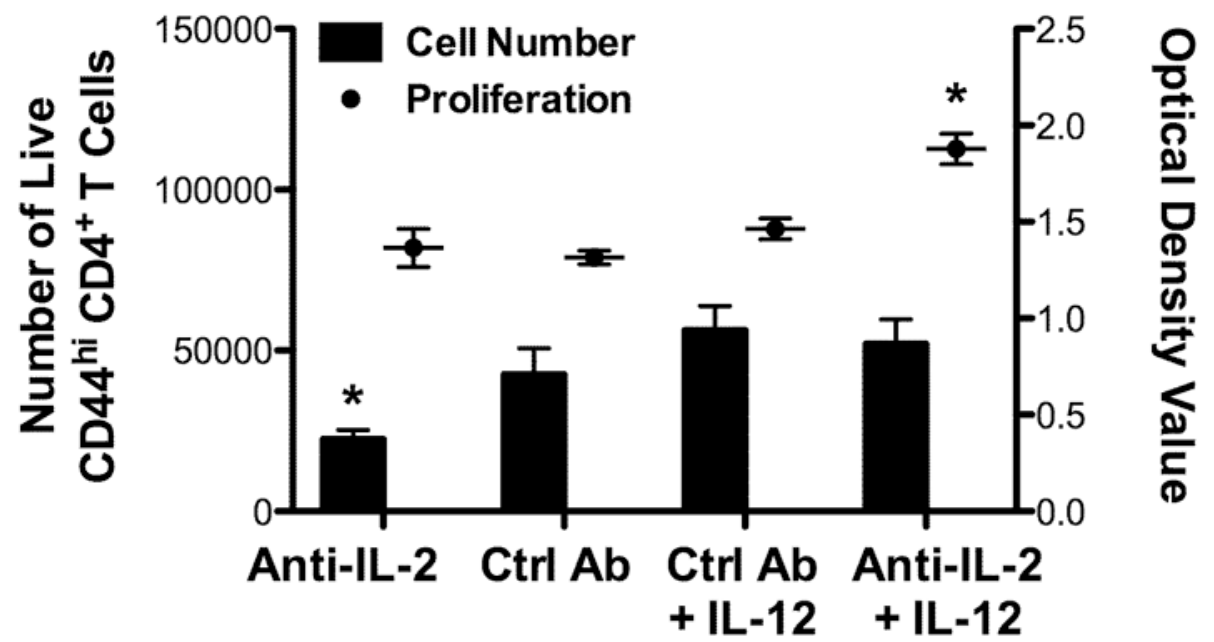

Figure 5.

IL-2 limits proliferation in response to IL-12 in vitro. CD4 ${ }^{+} \mathrm{T}$ cells were isolated from $L$. amazonesis-infected mice and cultured as described in materials and methods in the presence or absence of IL-2 and/or IL-12 (B) or with a neutralizing antibody against IL-2 or a control antibody in the presence or absence of IL-12 (D). To assess proliferation, cells were pulsed with BrdU during the final 12 hours of culture; BrdU incorporation was assessed via ELISA 24 hours post-secondary Ag restimulation (right axis, scatter plot). To assess cell numbers, the number of live $\mathrm{CD} 44^{\text {hi }} \mathrm{CD} 4^{+} \mathrm{T}$ cells was determined as described in materials and methods (left axis, bar graph). Data are represented as the mean \pm the SEM of three separate experiments except for treatment with IL-2 plus IL-12, which was two experiments. Experimental groups labeled a, b, c or * indicate a significant difference from one another at $\mathrm{p}<0.05$ as determined by Scheffe's test. 


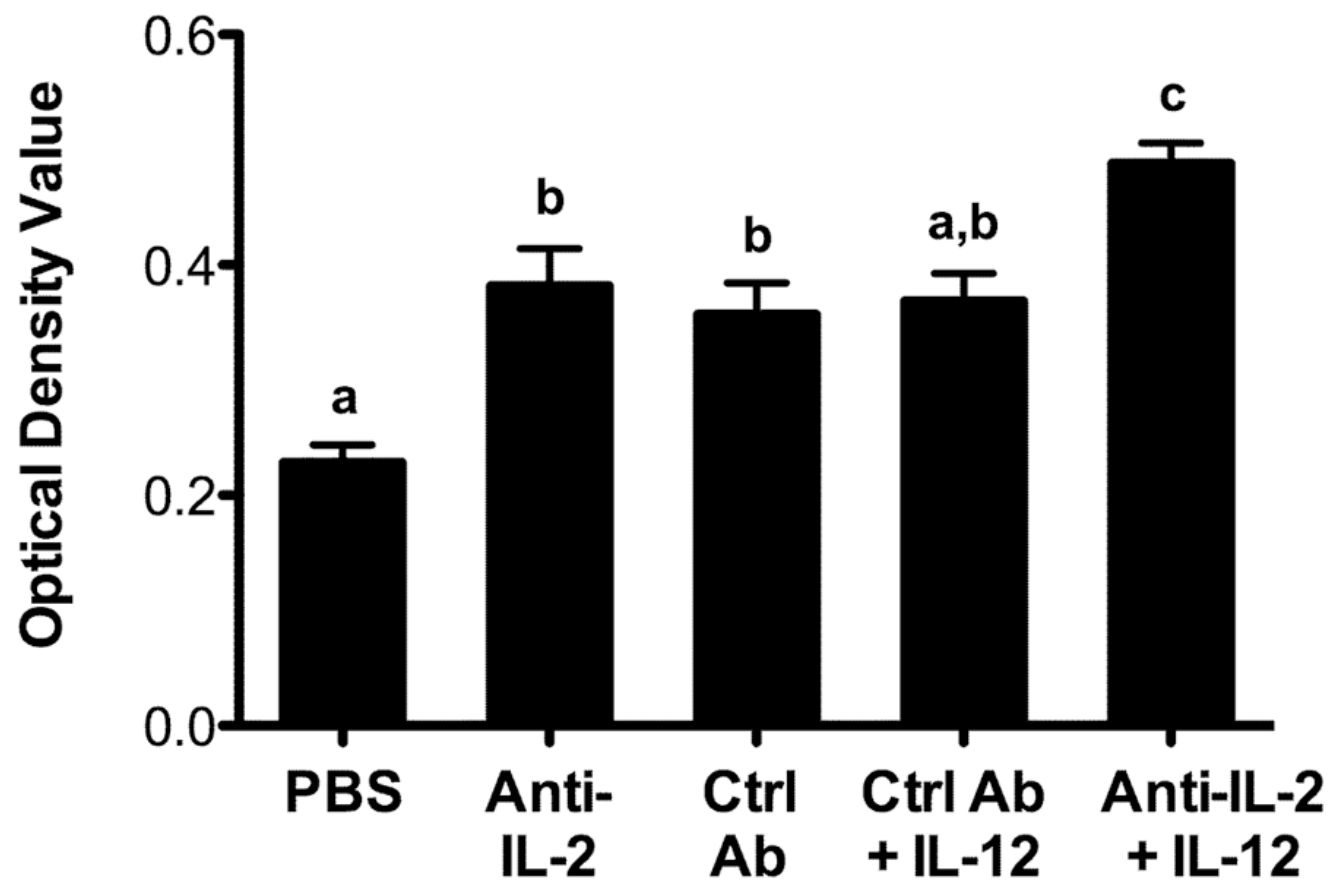

Figure 6.

IL-2 limits proliferation in response to IL-12 in vivo. L. amazonensis-infected mice were challenged in the contralateral footpad with Ag + PBS, Ag + anti-IL-2, Ag + isotype control antibody, Ag + control antibody + IL-12 or Ag + anti-IL-2 + IL-12. After 48 hours, lymph node cells draining the site of Ag challenge were harvested and stimulated in vitro with Ag for three days. Cultures were pulsed with BrdU during the final 12 hours; BrdU incorporation was assessed via ELISA. Data are represented as the mean \pm the SEM of two separate experiments. Treatments with different letters are significantly different from one another at $\mathrm{p}<0.05$ as determined by Scheffe's test. 